Public opinion supporting this stand, the high school curriculum was modified in 1956 to include two science subjects, and the enrolment in physies has now increased from 33 per cent to 75 per cent. Nevertheless the present arrangements for teaching physics in Japanese schools were reported by Haruo Ootuka (Tokyo) to be "almost completely unsuccessful".

The Western traditions which form the basis of these experiments are themselves under close scrutiny in the United States, where the Physical Science Study Committee has spent 5,000,000 dollars since 1956 on the preparation of a radically new curriculum for high school physics. The Committee's syllabus, intended for a one-year course to pupils aged 15-17 years, discards much that has been familiar to teachers and students during the past half-century, offering instead a penetrating analysis of selected topics contributing to a logical picture of the universe. The student who follows the course will know little about hydrostaties, the tangent galvanometer or the compound pendulum-but he will have measured the thickness of a tissue by counting interference fringes, he will have studied the Franck-Hertz experiment on atomic energy-levels, and he will have a working knowledge of vector kinematics.

Text-books and laboratory guides are supplemented by a large collection of films, some still in preparation, and by a series of paper-backed books.
Apparatus for experiment and demonstration is being manufactured at modest cost by an American scientific instrument firm.

More than 30,000 students have taken the course in its preliminary versions. A considerable expansion of the programme is expected when the literature and other teaching aids become available on a large scale towards the end of 1960 .

Many ideas brought forward in the discussions were underlined in the exhibition of apparatus, arranged by G. R. Noakes (Uppingham). The United States, Britain and France provided most of the material on view, but interesting contributions came from a few other European countries. Manufacturers showed real ingenuity in devising simple apparatus for studying and illustrating the principles of contemporary physies.

Speaking in Brussels on April 27, Lord Hailsham asked: "Can we feel sure that, in evaluating the methods of science teaching now in use, and the possible way in which they might be improved, we are ourselves approaching the matter scientifically? Can we be sure that we are practising what we preach ?" The International Conference on Physies Education has helped to answer this question. Further gatherings, perhaps with more limited objectives, would make a modest but distinctive contribution to the cause of education. J. M. A. LENIHAN

\title{
SEVENTH CONGRESS OF THE INTERNATIONAL SOIL SCIENCE SOCIETY
}

T HE seventh Congress of the International Soil Seience Society was held at Madison, University of Wisconsin, under the presidentship of Prof. Richard Bradfield of Cornell University, during August 15-23, with the motto "Promote Peace and Health throughout the World by alleviating Hunger through Soil Science". In the seventh Congress, sixteen hundred delegates, representing more than fifty countries, assembled and discussed nearly four hundred original contributions on different aspects of soil science and soil improvement in seven commissions or divisions. Moreover, there were seven general lectures and one symposium on tropical soil resources under the Food and Agriculture Organization. In the opening session on August 15, the members of the Congress were welcomed by the Governor of Wisconsin and the president of the University, and addresses were delivered by the director-general of the Food and Agriculture Organization, Mr. B. R. Sen, Prof. Bradfield and Dr. C. E. Kellog, the vice-president of the Congress.

Three tours were organized in which the activities and achievements of the universities and Government Departments of the United States in agriculture and soil conservation were demonstrated. Numerous soil profiles in many parts of the country were intensively studied and photographed. Lysimeter tests were exhibited at the soil and water conservation research station at Coshocton, Ohio.

The chief topics for study and discussion at the Congress were: soil classification, cartography and maps of soils, soil physics, moisture retention, irrigation, fertility, structure, morphology, soil chemistry, analysis, diagnosis, organic matter, humus, composts, soil fauna and soil formation, microorganisms, interaction of organic and inorganic matter in soils, clay minerals, genesis, the use of isotopes, liming, fertilization by nitrogen, phosphate, potash, trace elements, management of forest soil, saline soils, alkaline soils, etc.

Dr. F. E. Bear, a leader of soil science in the United States, in his report on "Soil in Relation to Nutritional Needs in Foods", stated that man can effect organic and mineral nutrient balance in his diet by taking a variety of plant products from many soils and meat, eggs and milk, but unfortunately such a selection is not always possible. Dr. G. D. Scarseth reported that the soils of humid tropics are highly leached and are poor, and when cleared for farming have to be adequately fertilized. According to Dr. K. H. Schütte and S. Amdurer, trace-element deficiency is widespread in South Africa. Dr. W. H. Allaway claimed that there is little evidence of harmful results from chemical fertilizers as envisaged by the late Dr. A. Carrel in his book "Man the Unknown".

In an important paper on the "Relation of Radioactive Contamination of Crops to Soil Fertility", Drs. R. F. Reitemeir and R. G. Menzel stated that the hazard associated with accumulation in the soil of the shorter-lived fission products, for example, iodine-131 and barium-140, is slight, but longerlived isotopes like strontium-89, strontium-90 and cæsium-137 are more dangerous. Addition of large amounts of organic matter to soil reduces the uptake of radio strontium and calcium. Prof. E. Turog 
described the development of soil testing methods in the United States during the past fifty years.

A large number of important communications on soil nitrogen, nitrification, nitrogen fixation, soil humus, composts, loss of nitrogen from soils, residual fertility, etc., were taken up in several sections of the Congress, because it is well established that nitrogen is the key element in cereal and other food production. Field trials in temperate countries show that one pound of nitrogen applied produces 16-17 lb. of cereals or other tillage crops, while in tropical countries the production is ten times the nitrogen input. This increase seems to be determined by the humus content in the soil ; the soil humus is greater in cool countries than in the tropics. It has been estimated that approximately 1,000 million tons of grains, including corn and 700 million tons of other food materials, are produced in the world at present. This food production requires 100 million tons of combined nitrogen. But the chemical nitrogen industry is providing 7 million tons, legumes 5 million tons, precipitation about 5 million tons and farmyard manure about 2 million tons in world agriculture. In the United States 1.5-2 million tons of chemical nitrogen, 2 million tons of legume nitrogen and perhaps 1 million tons of farmyard manure nitrogen are applied, although approximately 15 million tons of nitrogen are taken out annually from the 510 million acres of agricultural lands. Hence even to-day the majority of the nitrogen need of world crops is being met by the soil nitrogen, which must be augmented in permanent agriculture. One of the easiest methods of increasing the soil nitrogen is to plough in straw after removal of grains, cornstalks, dung, grasses, legumes, etc., mixed with 50-100 lb. phosphate (as Thomas (basic) slag) per acre, as advocated by Prof. N. R. Dhar in the Congress and elsewhere. In this manner $100 \mathrm{lb}$. of atmospheric nitrogen can be fixed per acre of land and this method is applicable to both tropical and temperate countries, which require an interval of 100-150 days for adequate nitrogen fixation and liberation of available nitrogen, phos- phate and potash for crop-growth in these lands. In this connexion, it is of interest to record that the British Association for the Advancement of Science meeting held in 1949 and presided over by Sir John Russell concluded that only 3 per cent of world food production could be attributed to artificial nitrogen. Moreover, as the application of phosphates increases the yield of crop to the extent of 5-7 times the amount of phosphorus incorporated in the soil, a very large number of papers on phosphorus availability, placement, etc., were considered at the congress.

In reaching Madison, Wisconsin, via Tour 1 and leaving Madison via Tours 2 and 3 , the delegates passed through the heart of the Corn Belt, located in the twelve North Central States, which occupy the upper portion of the Mississippi Valley. The United States produces more than half the world's maize and soy beans, and approximately one-sixth of the wheat. The bulk of these is produced in the prairie soils rich in nitrogen and humus, obtained by the natural incorporation of tall grasses in the land and by absorption of sunlight at the surface soil. It seems that no other large area in the world equals these parts of the United States as regards favourable conditions of soils (prairie, chernozem and grey-brown podzolic) and climate for the production of crops. The State of Iowa is the main producing area for maize and pork, Illinois for soy beans, Wisconsin for hay and canning crops and dairy products, which form one-seventh of the milk and half the cheese produced in the United States. The legume alfalfa (lucerne) is the main hay crop and is extensively grown.

The representatives of soil science, from many countries, including the U.S.S.R., Japan, China, India, South Africa, Ghana, Sudan, Congo and all European nations, assembled in Madison, and carried on deliberations in a cordial and friendly atmosphere for creating new knowledge, leading to the progress and welfare of the common man in the world and contributed to international friendship, co-operation and stabilizing world peace.

N. R. DHAR

\section{SOIL SURVEY IN THE WEST INDIES}

$\mathrm{U}^{\mathrm{s}}$ NDER the general direction of Dr. T. A. Jones steady progress has been made with the soil survey work of the Regional Research Centre of the British Caribbean, which has its headquarters at the Imperial College of Tropical Agriculture in Trinidad. The first three monographs to appear, namely, "The Parish of St. Catherine, Jamaica", "The Rupununi Savannas of British Guiana", and "St. Vincent" were reviewed in Nature, 184, 27 (1959). A further seven have now been published, covering another four of the parishes of Jamaica (St. Andrew, Clarendon, St. James and St. Mary), two further groups of selected areas in British Guiana and the island of Grenada (with Carriacou)*. Two other parishes of Jamaica are reported as completed, leaving six to be done. Each memoir follows the same plan, and as each is intended to be used as a self-contained guide there is a large amount of repetition. Each is

* Regional Research Centre of the British Caribbean at the Imperial College of Tropical Agriculture, Trinidad, W.I. Soil and Land-Use Surveys. Yonographs $4-10$. 1959-60. divided into three parts : (1) Factors affecting land use (climate, geology and lithology, relief and drainage, the people and their agriculture, present position of services); (2) the soils and their capabilities; (3) recommendations. Each monograph has a soil map in a pocket and for Jamaica the scale of $1: 50,000$ has been adopted; for Grenada the rather strange scale of $1: 18,750$ has been used. The use of a series of tints and symbols in red over a black outline has enabled much detailed information to be shown on the maps with, doubtless, a minimum of expense.

Although called a "Soil and Land-Use Survey" the existing land use has not in fact been surveyed: throughout, the aim is the severely practical one of relating potential use to soils. It is interesting to note that this has led to the re-use of the older approach to soil study-the grouping of the soils according to parent geological material-since it is found that this has the closest bearing on potential. Soil series are named and used, but take a subordinate place. In fact, Dr. Jones has given his reasons 